\title{
Medication reconciliation in pediatric patients with cancer at Brazilian public hospital
}

\author{
Nathalia Santos da PENHA ${ }^{1}$, Marcos Valério SILVA² (D), Mayara Arouck BARROS ${ }^{1}$, Tácio de Mendonça LIMA³ \\ ${ }^{1}$ Hospital Oncológico Infantil Octávio Lobo; ${ }^{2}$ Universidade Federal do Pará; ${ }^{3}$ Universidade Federal Rural do Rio de Janeiro \\ Corresponding author: Lima TM, taciolima@ufrrj.br \\ Submitted: 09-08-2018 Resubmitted: 04-05-2020 Accepted: 04-07-2020 \\ Peer review: blind reviewers
}

\begin{abstract}
Objective: This study aims to describe the discrepancies found through medication reconciliation performed by a clinical pharmacist in pediatric patients admitted to an oncology public hospital. Methods: A descriptive cross-sectional study was carried out in a North Brazilian oncology public hospital. Patients aged $0-19$ years old with any cancer diagnosis and/or stage were interviewed by a clinical pharmacist within 24 hours of hospital admission about their current medication use in order to develop an updated list to be compared with the medical prescription. Medication discrepancies were classified according the medication discrepancy taxonomy (MedTax). Results: One hundred and sixty-seven patients were screened for eligibility criteria. Of those, 160 patients were included in this study, with a mean age of $7.2 \pm 4.2$ years old; $58.2 \%$ were boys, taking a mean of $3.0 \pm 1.3$ drugs, and the most frequent primary diagnosis presented were leukemias (46.9\%) and malignant bone tumors (12.5\%). One hundred and twenty discrepancies were identified, of which $92.0 \%$ were unintentional discrepancies. Among them, $72.7 \%$ classified as omission, followed by frequency and/or number of units of dosage form and/or total daily dose (16.2\%), duration or length of therapy (7.2\%), and drug duplication (3.9\%). Ondansetron (37.3\%) was the drug more involved in these discrepancies. Conclusion: This study presented high unintentional discrepancies between the updated medication list and the medical prescription in pediatric patients with cancer, most of which classified such as inclusion. Our findings showed the importance of the clinical pharmacist to minimize medication errors in these patients.
\end{abstract}

Keywords: medication reconciliation, medication errors, patient safety, pharmacists.

\section{Conciliação de medicamentos em pacientes pediátricos oncológicos em um hospital público brasileiro}

\begin{abstract}
Resumo
Objetivo: Este estudo tem como objetivo descrever as discrepâncias encontradas na conciliação de medicamentos realizada pelo farmacêutico clínico em pacientes pediátricos internados em hospital público de oncologia. Métodos: Trata-se de um estudo descritivo, transversal, realizado em um hospital público de oncologia do norte do Brasil. Pacientes com idade entre 0 e 19 anos, com qualquer diagnóstico e/ou estágio do câncer, foram entrevistados por um farmacêutico clínico dentro de 24 horas da internação hospitalar sobre o uso atual de medicamentos, a fim de desenvolver uma lista atualizada para comparação com a prescrição médica. Discrepâncias de medicação foram classificadas de acordo com taxonomia de sobre discrepâncias de medicamentos (MedTax). Resultados: Cento e noventa e sete pacientes foram selecionados quanto aos critérios de elegibildiade. Destes, 160 pacientes (81,2\%) fora incluídos no studo, com idade média de 7,2 $\pm 4,2$ anos; $58,2 \%$ eram do sexo masculino, com média de 3,0 $\pm 1,3$ medicamentos em uso, com diagnósticos primários mais frequentes de leucemias $(46,9 \%)$ e tumores ósseos malignos (12,5\%). Foram identificadas cento e vinte discrepâncias, sendo 92,0\% discrepâncias não intencionais. Entre elas, 72,7\% foram classificados como omissão, seguidos de frequência, dosagem e dose diária (16,2\%), duração da terapia $(7,2 \%)$ e duplicação (3,9\%), sendo a ondansetrona (37,3\%) o medicamento mais frequente. Conclusão: Este estudo apresentou altas discrepâncias não intencionais entre a lista atualizada de medicamentos e a prescrição médica em pacientes pediátricos com câncer, sendo a maioria classificada como omissão. Nossos resultados mostram a importância do farmacêutico clínico em minimizar os erros de medicação nesses pacientes.
\end{abstract}

Palavras-chave: reconciliação de medicamentos, erros de medicação, segurança do paciente, farmacêuticos 


\section{Introduction}

According to the Federal Pharmacy Council, ${ }^{1}$ medication reconciliation is the service by which the pharmacist draws up an accurate list of all the drugs used by the patient, reconciling information from the medical record, prescription, patient, and caregivers, among others, being provided when the patient travels through different levels of care or through different health services, in order to reduce unintended discrepancies. It is a comprehensive assessment of a patient's medication regimen whenever there is a change in therapy, in an effort to avoid medication errors such as omissions, duplications, dosage errors or drug interactions, in addition to observing conformity standards and adherence to the treatment. ${ }^{2}$

A medication error, according to the Ministry of Health, ${ }^{3}$ is "like any preventable event that causes or induces the inappropriate use of a medication, being the medication under the control of the healthcare professional or of the patient", and may be present in any process of the professional practice. In an attempt to combat and reduce these errors, the World Health Organization $(\mathrm{WHO})^{4}$ launched in 2017 the third Global Challenge for Patient Safety, with the theme of "Medication without harms", whose purpose is to establish strategies to reduce by 50 percent the serious and preventable harms associated with medication errors in all countries over five years. Therefore, the medication reconciliation service becomes an indispensable practice to minimize this global problem, and the pharmacists are considered a crucial resource for the success of this process due to their collaboration with the multidisciplinary team and the patient. 2,5 A previous study had already demonstrated the positive impact on the reduction of discrepancies provided by medication reconciliation services led by pharmacists. ${ }^{6}$

In the context of pediatric patients, a review of the architecture reported high rates of drug discrepancies, ranging from $22 \%$ to $72.3 \% .^{7}$ Taking into account the medications for cancer, the adverse effects and the narrow therapeutic indexes expose patients to greater risks of potentially harmful medication errors. In general, the rate of chemotherapy errors is of $5 \%$ to $10 \%$ in studies of hospitalized patients and $25 \%$ in outpatients, with pediatric patients appearing to be at increased risk. ${ }^{8}$

Several studies have described medication reconciliation services in the hospital $\left.\right|^{9,10,11,12,13}$ and outpatient ${ }^{14,15}$ settings; however, this practice is not widely implemented in pediatric patients. ${ }^{16,17,18}$ Studies are limited to a specific niche studies, in a single center and with a reduced sample of patients. ${ }^{19}$ Furthermore, when it comes to oncology units, studies are more scarce. ${ }^{20}$

Thus, this study aims to describe the discrepancies found in medication reconciliation performed by the clinical pharmacist in pediatric patients admitted to a public oncology hospital.

\section{Methods}

This is a cross-sectional, descriptive and prospective study, carried out between July and October 2017, through the analysis of chemotherapy prescriptions and support therapies for pediatric patients admitted to a public oncology hospital in the state of Pará, linked to the Unified Health System (Sistema Único de Saúde, SUS) network.

The hospital unit is the first in the North region to be a reference in the treatment and diagnosis of childhood cancer, in the age group of 0-19 years old. The hospital has a five-story structure, with 89 hospital beds, 10 of which are intended for the Intensive Care Unit (ICU).
Pediatric patients ( 0 to 19 years old) hospitalized for prolonged chemotherapy infusion were included in the study, regardless of the type, classification and stage of the cancer protocol. Outpatients, and inpatients who were not undergoing chemotherapy, as well as patients or companions unable to communicate verbally were excluded. A non-probabilistic sampling for convenience was used.

The eligible patients were identified and recruited by the clinical pharmacist, previously trained, for interview in the first 24 hours of hospitalization. The pharmacist introduced himself to the patients and/or companions, providing information about the medication reconciliation service and asking about the use of usual medications (name of the medication, dose, route of administration, and frequency), including the use of over-the-counter (OTC) medications, supplements and herbal products, in order to obtain the "best possible medication history" (BPMH). In addition, to avoid forgetfulness bias, data in medical records regarding the nursing and the medical staff admisions were also collected. Based on this information, the clinical pharmacist developed a final list of drugs and compared it with the medical prescriptions received at hospital admission (chemotherapy and supportive therapies) to identify any discrepancies. This process was also conducted in the internal care transfers and at hospital discharge, as shown in Figure 1. The time taken to acquire the necessary information was obtained. All the collected information was filled in the data collection form and stored in a specific data sheet. Data collection was conducted continuously by the clinical pharmacist on weekdays from 8:00 am to 12:00 pm.

Figure 1. Flowchart of the medication reconciliation service

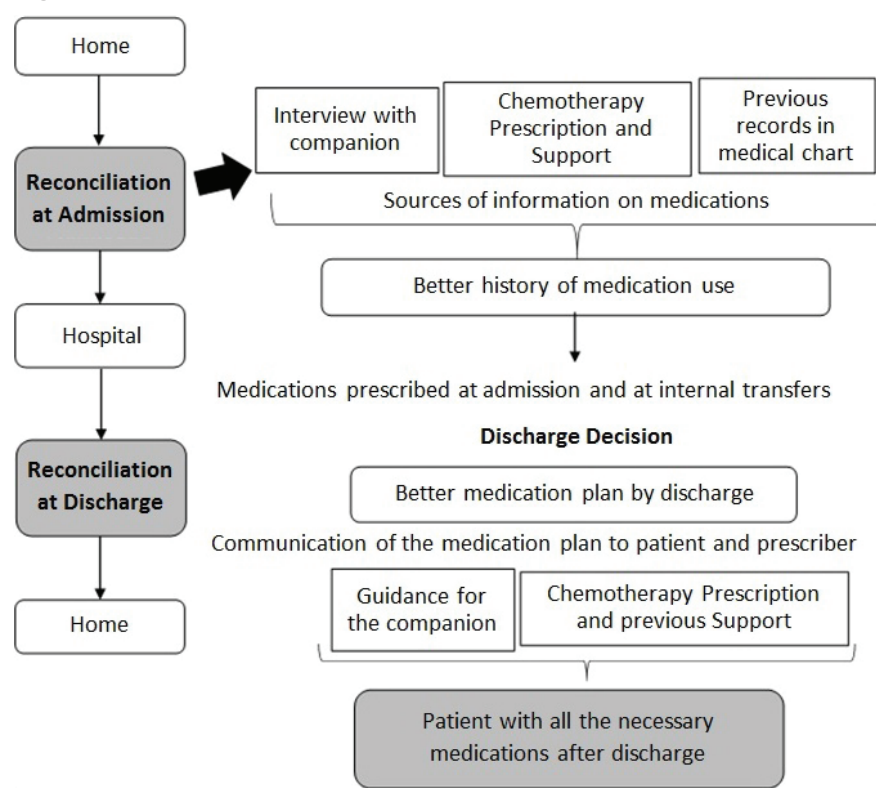

The discrepancy in medications was defined as any difference between the medication list based on the interview conducted by the clinical pharmacist and the list generated by the prescriptions at hospital admission. Discrepancies were classified according to the recently published MedTax ${ }^{21}$ taxonomy: omission (the drug is present in the updated list of medications but not in the prescription), addition (the drug is not present in the updated list of medication but is included in the prescription), duplication (duplication of therapy between the updated list of drugs and the medical prescription), replacement of the therapeutic class (the drug in the updated list of medications has been replaced by an 
alternative drug of the same class in the medical prescription), allergy or intolerance (the patient has an unwanted reaction/allergy to a certain type of medication and this medication is on the updated list of drugs), medication name (wrong or unclear name, and omission of the reference and/or generic name, among others), frequency, dosage and daily dose (inaccuracies in any of these parameters), dosage form and routes of administration (inaccuracies in each or both parameters), medication administration time (inaccuracies about medication administration time), and duration of therapy (inaccuracies in relation to differences in the start date, end date or duration of treatment), among others.

The prescriber was contacted in person or by phone in cases of unintended discrepancies. These cases were classified as medication errors and reported to the hospital's Quality Center.

Sociodemographic data such as the patient's gender, age, primary diagnosis, and number of medications in use were also collected and compiled in a pre-formatted spreadsheet. The organization, data recording, and statistical analysis were performed using the Exce $^{\circledR} 2010$ program. The analysis method included descriptive statistics, the results being expressed as absolute and/or relative frequencies, as well as a measure of association through Fisher's exact test, considering a 95\% confidence interval.

The research followed all the ethical precepts in force of Resolution CNS No. 466/12 of the National Health Council, having its project, Free and Informed Consent Form (FICF), as well as the Informed Consent Term, approved by the Ethics and Research Committee of the Health Sciences Institute of the Federal University of Pará with CAAE No. 70893817.1.0000.0018 and favorable opinion number 2,179,519.

\section{Results}

A total of 197 patients were selected for eligibility criteria. Of those, 160 patients (81.2\%) were included in the study. The mean age of the patients was $7.4 \pm 4.2$ years old, $58.5 \%$ being male and with a mean length of stay in the unit of $6.0 \pm 2.3$ days. The most frequent diagnoses presented were leukemias, myeloproliferative diseases and myelodysplastic diseases (46.9\%), followed by malignant bone tumors (12.5\%), lymphomas and reticuloendothelial neoplasms $(11.2 \%)$, soft tissue sarcomas (8,7\%), and others (20.7\%). The patients used a mean of $3.0 \pm 1.3$ medications.

The mean time taken to perform medication reconciliation was $30 \pm 10$ minutes. Of the total, 236 medications were reconciled, of which 120 (50.8\%) showed some discrepancy, with ondansetron being the most involved medication ( $n=87 ; 36.8 \%)$, followed by dipyrone $(n=29 ; 23.1 \%)$ and by dexamethasone $(n=22,9.3 \%)$. In $92.0 \%$ of the cases (110/120), the discrepancies were unintentional, characterizing medication errors. According to the MedTax ${ }^{21}$ taxonomy, omission was identified in $72.7 \%$ of the cases, followed by frequency, dosage and daily dose (16.4\%), duration of therapy (7.3\%) and duplication (3.6\%). Among the unintentional discrepancies, ondansetron was more often involved ( $n=41 ; 37.3 \%)$, followed by other drugs such as ibuprofen, morphine, and amitripline $(n=28 ; 25.4 \%)$. All of these discrepancies were communicated to the medical team for adequacy and decision making. Recommendations such as initiation/inclusion of therapy, dose adjustment/adequacy, frequency, and duration of medication use were addressed, with 100\% acceptability, without causing harms to the patient.

As for intentional discrepancies (8.0\%), omission was identified in $90.0 \%$ of the cases and was related to the non-need for the medication during the patient's hospitalization, and $10.0 \%$ in relation to the replacement of the standardized therapeutic class in the hospital. Regarding the intentional discrepancies observed, phenytoin was more involved $(n=5,50 \%)$, followed by fluconazole $(n=3,30 \%)$. The analysis of the association of intentional and unintentional discrepancies according to the characteristics of the study population and the drugs involved in intentional and unintentional discrepancies identified in the study are shown in Tables 1 and 2, respectively.

Table 1. Association of the intenttional or unintentional discrepancies according to the characteristics of the patients included in the study.

\begin{tabular}{|c|c|c|c|c|c|}
\hline \multirow{2}{*}{ Variables } & \multicolumn{2}{|c|}{$\begin{array}{l}\text { Total of patients } \\
\qquad(\mathrm{n}=160)\end{array}$} & \multirow{2}{*}{$\begin{array}{c}\text { Intentional discrepancies } \\
(\mathrm{n}=10)\end{array}$} & \multirow{2}{*}{$\begin{array}{l}\begin{array}{l}\text { Unintentional discrepancies } \\
(\mathrm{n}=110)\end{array} \\
\mathrm{n}(\%)\end{array}$} & \multirow{2}{*}{ p-value* } \\
\hline & n (\%) & Mean (SD) & & & \\
\hline Age (years old) & & $7.4(4.2)$ & & & \\
\hline$<10$ years old & $115(71.8)$ & & $3(30.0)$ & $49(44.5)$ & \\
\hline$\geq 10$ years old & $45(28.2)$ & & $7(70.0)$ & $61(55.5)$ & 0.51 \\
\hline \multicolumn{6}{|l|}{ Gender } \\
\hline Female & 67 (41.9) & & $4(40.0)$ & 46 (41.8) & \multirow{2}{*}{1.00} \\
\hline Male & $93(58.1)$ & & $6(60.0)$ & $64(58.2)$ & \\
\hline \multicolumn{6}{|l|}{ Diagnoses } \\
\hline $\begin{array}{l}\text { Leukemias, myeloproliferative diseases and } \\
\text { myelodysplastic diseases }\end{array}$ & $75(46.9)$ & & $5(50.0)$ & $53(48.2)$ & \multirow{5}{*}{0.99} \\
\hline Malignant bone tumors & $20(12.5)$ & & $1(10.0)$ & $16(14.5)$ & \\
\hline Reticuloendothelial lymphomas and neoplasms & $18(11.2)$ & & $1(10.0)$ & $10(9.1)$ & \\
\hline Soft tissue sarcomas & $14(8.7)$ & & $1(10.0)$ & $9(8.2)$ & \\
\hline Others & $33(20.7)$ & & $2(20.0)$ & $22(20.0)$ & \\
\hline Length of stay in the unit (days) & & $6.0(2.3)$ & & & \\
\hline$\leq 3$ days & $79(49.3)$ & & $6(60.0)$ & $47(42.7)$ & \multirow{2}{*}{0.33} \\
\hline$>3$ days & $81(50.7)$ & & $4(40.0)$ & $63(57.3)$ & \\
\hline Number of medications used & & $3.0(1.3)$ & & & \\
\hline$\leq 2$ & $87(54.3)$ & & $2(20.0)$ & $37(33.6)$ & \multirow{2}{*}{0.49} \\
\hline$>2$ & $73(45.7)$ & & $8(80.0)$ & $73(66.4)$ & \\
\hline
\end{tabular}


Table 2. Medications involved in intentional and unintentional discrepancies according to the MedTax taxonomy ${ }^{21}$ identified in the study.

\begin{tabular}{|c|c|c|c|c|c|c|c|c|}
\hline \multirow[b]{2}{*}{ Medications } & \multirow{2}{*}{$\begin{array}{c}\text { All } \\
n(\%)\end{array}$} & \multirow{2}{*}{$\begin{array}{c}\text { No } \\
\text { discrepancy } \\
n(\%)\end{array}$} & \multicolumn{2}{|c|}{ Intentional discrepancies } & \multicolumn{4}{|c|}{ Unintentional discrepancies } \\
\hline & & & $\begin{array}{c}\text { Omission } \\
\text { n (\%) }\end{array}$ & $\begin{array}{c}\text { Substitution of the } \\
\text { therapeutic class } \\
\text { n (\%) }\end{array}$ & $\begin{array}{l}\text { Omission } \\
\text { n (\%) }\end{array}$ & $\begin{array}{c}\text { Frequency, dosage } \\
\text { and daily dose } \\
\text { n (\%) }\end{array}$ & $\begin{array}{c}\text { Duration of } \\
\text { the therapy } \\
\text { n (\%) }\end{array}$ & $\begin{array}{c}\text { Duplication } \\
\text { n (\%) }\end{array}$ \\
\hline Ondansetron & $87(36.8)$ & $46(39.7)$ & - & - & $36(45.0)$ & $1(5.5)$ & - & $4(100.0)$ \\
\hline Dipyrone & $29(12.3)$ & $6(5.3)$ & - & - & $20(25.0)$ & $3(16.6)$ & - & - \\
\hline Dexamethasone & $22(9.3)$ & $14(12.0)$ & - & - & $8(10.0)$ & - & - & - \\
\hline Methotrexate & $16(6.8)$ & $14(12.0)$ & - & - & - & $2(11.2)$ & - & - \\
\hline Fluconazole & $11(4.7)$ & $2(1.7)$ & $3(33.3)$ & - & $3(3.8)$ & - & $3(37.5)$ & - \\
\hline Vincristine & $10(4.2)$ & $10(8.6)$ & - & - & - & - & - & - \\
\hline Doxorubicin & $10(4.2)$ & $8(6.9)$ & - & - & - & $2(11.2)$ & - & - \\
\hline Calcium folinate & $8(3.4)$ & $8(6.9)$ & - & - & - & - & - & - \\
\hline Phenytoin & $5(2.2)$ & - & $5(55.5)$ & - & - & - & - & - \\
\hline Others & $38(16.1)$ & $8(6.9)$ & $1(11.2)$ & $1(100.0)$ & $13(16.2)$ & $10(55.5)$ & $5(62.5)$ & - \\
\hline
\end{tabular}

\section{Discussion}

To our knowledge, this is the first study that described drug discrepancies through a medication reconciliation service provided by the clinical pharmacist in pediatric cancer patients at a public hospital in northern Brazil. This study allowed for the inclusion of the clinical pharmacy in an institutionalized manner in the hospital, expanding knowledge about the medication reconciliation service, in addition to promoting greater interaction with the multidisciplinary team and with patients and family members.

The importance of medication conciliation is recognized by international organizations such as the Joint Commission Accreditation of Healthcare Organizations $(\mathrm{JCAHO})^{22}$, being a key service for improving patient safety through the identification of drug discrepancies. ${ }^{23}$ In this study, 120 discrepancies were identified, similarly to some studies ${ }^{15,24}$ and differently from others ${ }^{16,17,20,25}$. The difference in the results presented is mainly due to the differences in the sample sizes and in the study period.

Medication errors are present in the daily routine of the clinical practice, especially at hospital admission..$^{26,27}$ Our study identified a large number of unintentional medication divergences (92.0\%), corroborating with data published in previous studies, in which a high percentage of admitted patients had unintentional discrepancies. ${ }^{12,14,18}$ It is important to note that the presence of the clinical pharmacist, as well as his recommendations, prevented harms to the patients, highlighting the importance of the professional in this service.

Most of the unintended discrepancies found in our study were classified as omissions (approximately $73 \%$ ), similarly to other findings in the literature. ${ }^{10,12,16-18}$ However, it is important to note that different classifications were used to identify discrepancies in medications. A previous systematic review already signaled the lack of a universal classification to identify these discrepancies. ${ }^{23}$ Our study used the MedTax ${ }^{21}$ taxonomy proposed by the same authors and recently validated. Thus, care should be taken when comparing these previous results with the findings of this study. It is important to analyze the meaning of each classification so that any comparisons can be made reliably.
In this study, a higher frequency of unintended discrepancies with ondansetron was observed, an antiemetic widely used as supportive therapy in chemotherapy treatment. These findings differ from the data presented by Schuch et $\mathrm{al}^{20}$ in a similar study, observing a higher frequency of unintended discrepancies with antineoplastic agents due to the characteristic of the study population. However, this study also observed these discrepancies with antineoplastic agents, as in the case of metrotexate, doxorubicin, cyclophosphamide, and topotecan, demonstrating the importance of reconciling high-risk drugs.

The improvement of the interview with the patient/caregiver, as well as the improvement of the collection of information about medications and the correct documentation of the data in medical records can be decisive for reducing medication errors. ${ }^{28}$ In this study, in addition to the interview with the patient/caregiver, and considering that some data could be omitted due to forgetfulness, the search for information in medical records and with the multidisciplinary team was conducted in order to guarantee the best possible history of the medication.

The mean time taken to obtain data for performing medication reconciliation was high compared to other studies. ${ }^{10,29}$ The process for obtaining the medication history requires considerable time and specific skills, and training aimed at developing this practice is recommended. ${ }^{30}$ The time used can express benefit, if we interpret that it is associated with the greater detail of the collection of the medication history, or even more time spent in the discussion of the discrepancies with the prescribing physician. However, it can be seen as a non-optimized work process, or as lack of training or experience of the pharmacists who performed the service.

Our study presented some limitations. Its cross-sectional and descriptive nature limits to only one observation in time. Choosing the sample for convenience can introduce bias in relation to the general population subject of the study. The clinical meanings of the unintentional discrepancies identified were not analyzed. In addition, the associations between the variables and the number of discrepancies were not assessed. Finally, the results must be interpreted with caution because the study is conducted in a single center. 


\section{Conclusion}

Our results showed a high number of unintended discrepancies found in pediatric cancer patients in a public hospital, most of which were classified as omissions. On the other hand, the discrepancies identified were resolved without causing harms to the patients, showing the importance of the clinical pharmacist and of the medication reconciliation service to minimize medication errors.

\section{Funding sources}

There were no external funding sources for the realization of this study.

\section{Collaborators}

NSP collected and interpreted the study data. TML interpreted the data and wrote the article. NSP, MVSS, MAB critically reviewed the article. MVSS coordinated the study project. All the authors are responsible for the information presented in the article and have approved the final version for publication.

\section{Conflict interest statement}

The authors declare that there are no conflicts of interest regarding this article.

\section{References}

1. Conselho Federal de Farmácia. Serviços farmacêuticos diretamente destinados ao paciente, à família e à comunidade contextualização e arcabouço conceitual. Brasília: CFF, 2016.

2. American Pharmacists Association, American Society of Health-System Pharmacists. Improving care transitions: optimizing medication reconciliation. J Am Pharm Assoc. 2012;52(4):e43-e52.

3. Brasil. Ministério da Saúde. Agencia Nacional de Vigilância Sanitária. Protocolo de segurança na prescrição, uso e administração de medicamentos do programa nacional de segurança do paciente. 2013.

4. World Health Organization. WHO. Medication without harm: WHO's third global patient safety challenge. Geneva: WHO, 2017.

5. Merandi J, Sapko M, Catt C, Hoffman JM. Medication Reconciliation. Pediatr Rev. 2017;38;54-55.

6. Mekonnen AB, McLachlan AJ, Brien JA. Pharmacy-led medication reconciliation programmes at hospital transitions: a systematic review and meta-analysis. J Clin Pharm Ther. 2016;41(2):128-44

7. Huynh C, Wong IC, Tomlin S, et al. Medication discrepancies at transitions in pediatrics: a review of the literature. Paediatr Drugs. 2013;15(3):203-15

8. Weingart SN, Zhang L, Sweeney $M$, et al. Chemotherapy medication errors. Lancet Oncol. 2018;19(4):e191-e199.

9. Presley CA, Wooldridge KT, Byerly SH, et al. The Rural VA Multi-Center Medication Reconciliation Quality Improvement Study (R-VA-MARQUIS). Am J Health Syst Pharm. 2020 Jan $8 ; 77(2): 128-137$.
10. Chun DS, Faso A, Muss HB, et al. Oncology pharmacist-led medication reconciliation among cancer patients initiating chemotherapy. J Oncol Pharm Pract. 2019;18(0):1-8.

11. Abdulghani $\mathrm{KH}$, Aseeri MA, Mahmoud A, et al. The impact of pharmacist-led medication reconciliation during admission at tertiary care hospital. Int J Clin Pharm. 2018;40(1):196-201.

12. Spalla LR, Castilho SR. Medication reconciliation as a strategy for preventing medication errors. Braz J Pharm Sc. 2016;52(1):143-150.

13. Allende Bandrés MÁ, Arenere Mendoza M, Gutiérrez Nicolás $F$, et al. Pharmacist-led medication reconciliation to reduce discrepancies in transitions of care in Spain. Int J Clin Pharm. 2013;35(6):1083-90.

14. Koprivnik S, Albiñana-Pérez MS, López-Sandomingo L, et al. Improving patient safety through a pharmacist-led medication reconciliation programme in nursing homes for the elderly in Spain. Int J Clin Pharm. 2020;28.

15. Lima TM, Gonçalvez MCD, Figueiredo IV. Medication Discrepancies in Older Adults in Portugal's Primary Health Care. Rev Port Farmacoter. 2018;10:106-110.

16. Iturgoyen-Fuentes DP, Martin-Aragon S, Cuervas-Mons Vendrell $\mathrm{M}$. Medication reconciliation upon admission in paediatric hospital setting: preliminary data. Int J Clin Pharm. 2020;9.

17. Farha RA, Hammour KA, Al-Jamei S, et al. The prevalence and clinical seriousness of medication discrepancies identified upon hospital admission of pediatric patients. BMC Health Serv Res. 2018;18(1):966.

18. Gattari TB, Krieger LN, Hu HM, et al. Medication Discrepancies at Pediatric Hospital Discharge. Hosp Pediatr. 2015;5(8):439445 .

19. Huynh C, Tomlin S, Jani $Y$, et al. An evaluation of the epidemiology of medication discrepancies and clinical significance of medicines reconciliation in children admitted to hospital. Arch Dis Child. 2016;101(1):67-71.

20. Schuch AZ, Zuckermann J, Santos MEF, et al. Reconciliação de medicamentos na admissão em uma unidade de oncologia pediátrica. Rev. Bras. Farm. General Serv. Saúde. 2013;4(2):35-39.

21. Almanasreh E, Moles R, Chen TF. The medication discrepancy taxonomy (MedTax): The development and validation of a classification system for medication discrepancies identified through medication reconciliation. Res Social Adm Pharm. 2020;16(2):142-148.

22. The Joint Comission Accreditation of Healtcare Organizations. National Patient Safety Goals Effective January 2019. [Internet]. Hospital Accreditation Program; 2019. Available in: https://www.jointcommission.org/-/media/tjc/documents/ standards/national-patient-safety-goals/npsg_chapter_hap_ jan2019. pdf? db=web\&hash=3060F486CA146BD9071F7C2DBF7796A4. Accessed March 3, 2020.

23. Almanasreh $\mathrm{E}$, Moles $\mathrm{R}$, Chen TF. The medication reconciliation process and classification of discrepancies: a systematic review. Br J Clin Pharmacol. 2016;82(3):645-58.

24. Lombardi NF, Mendes AEM, Lucchetta RC, et al. Análise 
das discrepâncias encontradas durante a conciliação medicamentosa na admissão de pacientes em unidades de cardiologia: um estudo descritivo. Rev Lat Am Enfermagem. 2016;24(0):1-7.

25. DeCourcey DD, Silverman M, Chang E, et al. Medication Reconciliation Failures in Children and Young Adults with Chronic Disease During Intensive and Intermediate Care. Pediatr Crit Care Med. 2017;18(4):370-377.

26. Cornish PL, Knowles SR, Marchesano R, et al. Unintended medication discrepancies at the time of hospital admission. Arch Intern Med. 2005;165(4):424-9.

27. Duguid $M$. The importance of medication reconciliation for patients and practioners. Aust Prescr 2012;35:15-9.

28. Drenth-van Maanen AC, Spee J, van Hensbergen L, et al. Structured history taking of medication use reveals iatrogenic harm due to discrepancies in medication histories in hospital and pharmacy records. J Am Geriatr Soc. 2011;59(10):19767.

29. Gomes AD, Galato D, Silva EV. Erros de prescrição de medicamentos potencialmente perigosos em um hospital terciário. Rev. Bras. Farm. General Serv. Saúde. 2017;8(3):427.

30. Dersch-Mills D, Hugel K, Nystrom M. Completeness of information sources used to prepare best possible medication histories for pediatric patients. Can J Hosp Pharm. 2011;64(1):10-15. 